\title{
Concept and simulation of an unmanned agricultural spraying aircraft
}

João Carlos Teles Ribeiro da Silva ${ }^{1}$

Kamal A. R. Ismail

\section{Abstract}

In recent years, the Brazilian agriculture production expanded by $900 \%$ over 1990, while the cultivated areas increased at a rate of $2 \%$ per year. Due to this expansion, pulverization turned from manual to mechanical using ground equipment and aircraft. As a result of the new tendencies, recent statistics show the negative impacts on the health of pilots and operators of terrestrial machinery and on the environment. The present study evaluates the concept of an unmanned aerial vehicle (UAV) for pulverization of defensive products, named here as AVANT. In this study, new airfoils are evaluated, lifting line technique, vortex and panels method are used to define the geometry of the wings, fuselage and tail elements. Simulations were realized to verify the performance of the AVANT during operational shots and maneuvers. The basic parameters of the proposed AVANT are, Wingspan: 6 m; Monoplane; High wing; Piston engine (gasoline); Propeller; Tractor type; Installed power: 18 hp; Length: 5.5 m; Height: 1.477 m; Tail dragger type; Tail width: 2.6 m; Empty weight: 108.585 kg; Gross weight: 150 kg; Maximum Endurance: 9 h; Fuel capacity: 28 L; Agrochemicals capacity: 20 L; The results show that the AVANT is adequate for the proposed application.

Keywords: Aerodynamics. Agriculture. Pesticides. UAV.

\section{Introduction}

Cases of intoxication among rural workers have increased due to the inappropriate use of pesticides; domestic animals are also affected by this. Also, the considerable waste of the chemicals creates serious risks to the environment in general. Food contamination is also a concern in this regard (PALLADINI, 2019).

In contrast, Huang et al. (2009) indicated that the application of defensives for crop production is a crucial component in the high productivity of developed countries' agriculture, suggesting a Vertical Take-Off and Landing (VTOL) unmanned autonomous helicopter (SR200) powered by a two-stroke gasoline engine. SR200 UAV helicopter had a gross weight of $22.7 \mathrm{~kg}$, a low volume spray rate of $0.3 \mathrm{~L} \mathrm{ha}^{-1}$, two nozzles, and two gasoline tanks with a volume of $7.56 \mathrm{~L}$ each required spraying 14 ha.

The agricultural production system focused on obtaining high rates of productivity has used routinely the practice of applying phytosanitary products, which is an essential practice in the current system. However, the persistent occurrence of poorly regulated agricultural sprayers with worn or improperly selected nozzles, and pesticides with dosages calculated and executed erroneously,

1 Instituto Federal de Educação, Ciência e Tecnologia do Sul de Minas Gerais (IFSULDEMINAS), Campus Muzambinho. joao.silva@muz.ifsuldeminas.edu.br

2 Universidade de Campinas (UNICAMP). kamal@fem.unicamp.br 
make this practice inefficient and with harmful impacts on the environment (SCHMIDT; ZANELLA, 2017; CHAIM, 2019). Thousands of cases of diseases and health problems of rural workers who have long direct contact with pesticides and fertilizers have long been known. Manual spraying can bring damage to the worker's health (MOGILI; DEEPAK, 2018), however, either for tractor spraying or even aerial spraying, the damages to the health of the tractor drivers and pilots is equally serious and dangerous due to the long direct contact with these products and the high rates of fatal accidents.

Agrochemicals application is one of the most critical issues of the current agricultural production system (SILVA et al., 2015; YANAGIHARA; BRAGAGNOLO, 2018), being an obstacle that raises the production cost and can lead to direct and indirect damages to the environment (WACHTEL et al., 2019) and the agriculture workers (JUNQUEIRA; CONTRERA, 2018).

Moreover, despite the great worldwide concern regarding the use of suitable pesticides and fertilizers, what happens in the real world is neglect, especially in developing countries, leading to contamination and health damage of rural workers (MARCELINO; WACHTEL; GHISI, 2019). Apart from that, contamination of rivers and groundwater reduces fauna and flora not only in the surrounding areas but reaching forests and cities. The inappropriate use of agrochemicals can contaminate underlying soils and groundwater (ABUBAKAR et al., 2015; KELLY; COHEN, 2018).

According to Reeves et al. (2019), understanding the magnitude and impact of dietary pesticide exposures is a concern for some consumers and rural workers and their families (OJO, 2016). Sena et al. (2018) indicated that in the work environments, different physical and chemical agents coexist and may pose a risk to workers' health and their families. Buralli et al. (2018) reported the respiratory condition of farmers' families exposed to pesticides in the State of Rio de Janeiro, Brazil. They also claim that pesticide exposure is a growing public health concern.

The World Health Organization (WHO) estimates the order of one million cases of human health problems caused by manual spraying. Thus, the unmanned aerial vehicle (UAV) is the alternative solution to be used to spray agrochemicals to avoid the thousands of cases of health problems, humanizing this agricultural operation (MOGILI; DEEPAK, 2018).

UAVs are more maneuverable, cheaper to operate, and require fewer capital costs, which may serve to address this need in agricultural operation (HUANG et al. 2009).

The literature review highlights the need to develop the aerodynamic concept of an unmanned agricultural aircraft suitable for spraying. Therefore, the present study has the objective of contributing to this area of application to make it more adequate and less harmful to the environment and workers. For this purpose, the work of Matsuo and Ismail (2010) was used as a basis and starting point.

Recent scientific research demonstrates the use of spray UAVs (FAIÇAL et al., 2014; FAIÇAL et al., 2017; LING et al., 2018; XUE et al., 2016; ZHANG et al., 2018; ZHU et al., 2010). However, most of these UAVs are configured as quadcopters or octocopters, with few studies focusing on unmanned monoplane for the pulverization applications, with a large number of studies focused on electronic modeling, not on the aerodynamic concept. Matsuo and Ismail (2010) proposed an unmanned monoplane for spray application.

On electronic modeling, a new technology in the fields of plant protection and pest control in China, a plant protection UAV variable spray system based on neural networks, the UAV code was validated with wind tunnel tests and the factors affecting droplet deposition including ambient temperature, ambient humidity, wind speed, flight speed, flight altitude, propeller pitch and nozzles pitch (WEN et al., 2019). 
Several researches pointed out the necessity to provide data support to spray drift control and to the establishment of aviation spray standards (WANG et al., 2017). Under these conditions, Meivel et al. (2016) proposed a quadcopter UAV based fertilizer and pesticide spraying system for Indian agriculture, denoting that a remote-controlled UAV, to spray the pesticide as well as fertilizer to avoid the humans' health hazards. Yongjun et al. (2017) proposed a six-rotor UAV operated at different heights and velocities to test pesticides spray effects for corns at different growth stages.

Wang et al. (2019) indicated that UAVs are a recently developed aerial spraying technology and they assessed the effect of spray volume variation on deposition and pesticide control efficacy.

For the modeling of any aerodynamic system, it is appropriate to apply the panel method (YU; GUAN, 2015). The panel method can also be used to optimize airfoils as well as to calculate, before and after optimization, the coefficients of lift and pressure. Therefore, the optimization of the NACA 0012 aerodynamic profile was performed by the researchers Jafarimoghaddam and Aberoumand (2016) through the vortex panels method, resulting in a new aerodynamic that presents a greater aerodynamic efficiency for high or low-speed flights.

There is another largely used method, the Vortex Lattice Method (VLM). A new nonlinear formulation of the classic VLM method has been used to modify the wing of the UAV to increase its aerodynamic efficiency and to calculate the reductions in the drag, this method was proposed by Gabor, Koreanschi and Botez (2016).

Finally, the main objective of this work is the aerodynamic concept of an unmanned agricultural spraying aircraft and computational simulation of its operation surveying its velocity variance, the center of gravity variation, fuel consumption, endurance and range.

Therewith the present study is based on the technical rules of the Brazilian Regulation of Aeronautical Homologation (RBHA), which refer to the Federal Aviation Administration of the United States of America (FAA), and the European JAR (Joint Aviation Requirements) from the EASA agency, European Aviation Safety Agency.

The notable innovation of this paper is the analysis of the aerodynamic behavior of the aircraft in each spray shot, aiming at the stability and the operability throughout the agricultural task. Besides, this mathematical model focuses on an airplane that has a minor impact on the environment and therewithal the humanization of the spraying operation.

Thereby, the calculation methodology was presented first, followed by the spray tank volume and flow values, spray nozzle specifications, flight and operating conditions, and finally the mission layout. From this, aircraft loading, aircraft design parameters, power versus velocity curves, AVANT's three-view diagram, full-scale pressure coefficient distribution and the final characteristics of AVANT were presented.

Withal the aerodynamic concept of the spraying monoplane, total spray flow variation for each spray shot was surveyed, thereupon; it being regarded the position variance of the AVANT's center of gravity throughout the agricultural task.

It is noteworthy that there was no product built, since the present work aimed at mathematical modeling, calculations and computer simulations.

\section{Material and methods}

The routines used in the mathematical modeling for the aerodynamic calculations of the AVANT were implemented in Fortran. The lift coefficients of the complete aircraft were calculated for the wing 
and tail by the VLM, modeled as non-thickened surfaces, and for the fuselage, the calculations were done by the Panel Method.

The method of the panels (JAFARIMOGHADDAM; ABEROUMAND, 2016; RAMOS-GARCÍA; SØRENSEN; SHEN, 2016; YU; GUAN, 2015) is widely used in the calculation of aerodynamic coefficients for various applications, such as design of wings, turbines, propellers, fuselages, and complete aircrafts, among others. Another method widely diffused in aerodynamic calculations is VLM (GABOR; KOREANSCHI; BOTEZ, 2016).

The Vortex Lattice Method is suitable for the calculations of lifting surfaces such as wing and tail stabilizers. The potential flow definition used in the VLM is analogous to electrical potential theory. In the case of fluid dynamics, the field is defined as an incompressible flow (Eq. 1), at which the velocity field depends on the gradient between the equipotential (Eq. 2), and irrotational lines (Eq.3), being governed by the equations:

$$
\begin{aligned}
\nabla \cdot \vec{V} & =0 \\
\nabla \cdot \vec{V} & =\nabla \phi \\
\nabla^{2} \phi & =0
\end{aligned}
$$

In which: $\vec{V}=$ field velocity vector $\left[\mathrm{m} \mathrm{s}^{-1}\right] ; \phi=$ equipotential lines.

Infinite vortices line induces a flow field around a line with the induced flux perpendicular to the radius and the force inversely proportional to the radius. For a vortex segment, the induced field is defined by the Biot and Savart law (Eq. 4), at which the elemental of V, in this case, refers to the induced velocity:

$$
d \vec{V}_{\text {ind }}=\frac{\vec{\Gamma} \cdot(d \vec{l} \times \vec{r})}{4 \pi|\vec{r}|^{2}}
$$

In which: $\vec{\Gamma}=$ vorticity [m s $\left.\mathrm{m}^{-1}\right] ; \vec{l}=$ length of the vortex segment [m]; $\vec{r}=$ radius between the vortex line and the induced flow line [m].

Accordingly, Eq. 4 must be integrated to calculate the induced velocity, and the pressure depends on this value and can then be calculated by Bernoulli's Theorem.

This induced flow can be used to obtain the force acting on each panel using the KuttaZhukovsky's theorem, Eq. 5 (MATSUO; ISMAIL, 2010).

$$
\vec{L}=\rho\left(\vec{V}_{\text {ind }} \times \vec{\Gamma}\right) \cdot \vec{l}
$$

In which: $\rho=$ specific mass of the free air stream $\left[\mathrm{kg} \mathrm{m}^{-3}\right] ; \vec{L}=$ lifting force $[\mathrm{N}]$.

An arbitrary finite number of panels, in the Vortex Lattice Method, results in the system represented by Eq. 6 , in which, $\Gamma$ is unknown, $w$ is the parameterization of each vortex of each panel and $b$ is the parameterization of flight conditions (like attack angle, slippage, among others) of each panel. 


$$
\left[\begin{array}{ccc}
W_{11} & \cdots & w_{1 n} \\
\vdots & \ddots & \vdots \\
W_{n 1} & \cdots & w_{n n}
\end{array}\right] \cdot\left[\begin{array}{c}
{ }_{1} \\
\vdots \\
{ }
\end{array}\right]=\left[\begin{array}{c}
b_{1} \\
\vdots \\
b_{n}
\end{array}\right]
$$

As for the Panel Method, the panel discretization was done in which , a normal unitary vector, is assigned a pressure differential transformed in the same direction as the normal unitary vector, depending on the velocity of the free stream, the specific air mass and the Mach number.

Each panel has a point $(x 0, y 0)$ on the lifting surface in which is applied. The local load applied at $(x O, y 0)$ induces a velocity w over an arbitrary point $(x, y)$. As a simplification, the integral is discretized by a constant approach by parts as in Eq 7 .

$$
\left[\begin{array}{c}
W_{1} \\
\vdots \\
w_{n}
\end{array}\right]=\left[\begin{array}{ccc}
c_{11} & \cdots & c_{1} n \\
\vdots & \ddots & \vdots \\
c_{n 1} & \cdots & c_{n n}
\end{array}\right] \cdot\left[\begin{array}{c}
p_{1} \\
\vdots \\
p_{n}
\end{array}\right]
$$

In which: $w=$ velocity induced by each panel $\left[\mathrm{m} \mathrm{s}^{-1}\right] ; c=$ elements of the coefficient matrix of all panels; $p=$ load vector elements on all panels $\left[\mathrm{N} \mathrm{m}^{-2}\right]$.

The coefficient matrix was calculated by Eq. 8 for each $\delta$ s panel, and this equation integrates $K$, from the Kernel Function Method.

$$
c=\iint_{\delta s} K\left(x-x_{0}, y-y_{0}\right) d x_{0} d y_{0}
$$

The operation site for the UAV aircraft was the rural area of the municipality of Muzambinho/MG, Brazil, location: $21^{\circ} 22^{\prime} 33^{\prime \prime}$ S, 46 31' 33" W; Meso-region: Southern of Minas Gerais. Therefore, the physical characteristics of this air were considered (Table 4). The total drag coefficient of the aircraft is given by:

$$
C_{D}=C_{D, 0}+C_{D, i}
$$

In which: $C_{D}=$ total drag coefficient, dimensionless; $C_{D, 0}=$ zero lift drag coefficient, dimensionless; $C_{D, i}=$ induced drag coefficient, dimensionless.

The aerodynamic efficiency is the ratio of the lifting force and the drag force, and its maximum value given by:

$$
\left(\frac{C_{L}}{C_{D}}\right)_{\max }=\frac{\left(C_{D, 0} \pi \mathrm{e} A\right)^{\frac{1}{2}}}{2 C_{D, 0}}
$$

In which: $\mathrm{C}_{\mathrm{L}}=$ lift coefficient, dimensionless; $\mathrm{e}=$ Oswald's factor, dimensionless; $\mathrm{A}=$ aspect ratio, dimensionless. 
For propeller-powered aircraft, another important parameter related to aerodynamic efficiency is the lift coefficient raised to three means on the drag coefficient, given by:

$$
\left(\frac{C_{L}^{\frac{3}{2}}}{C_{D}}\right)_{\max }=\frac{\left(3 C_{D, 0} \pi e A\right)^{\frac{3}{2}}}{4 C_{D, 0}}
$$

With the drag force value, the power required is given by:

$$
P_{R}=W V\left(\frac{C_{L}}{C_{D}}\right)^{-1}
$$

In which: $\mathrm{P}_{\mathrm{R}}=$ power required [W], known as $1.0 \mathrm{hp}$ is equal to $745.7 \mathrm{~W} ; \mathrm{W}=$ aircraft weight $[\mathrm{N}] ; \mathrm{V}=$ aircraft velocity $\left[\mathrm{m} \mathrm{S}^{-1}\right]$.

With the value of the required power, the value of the engine power was calculated. The engine is designed to allow the aircraft to perform maneuvers. Thus, the available power is given by:

$$
P_{A}=\eta P
$$

In which: $P_{A}=$ available power $[W] ; P=$ engine shaft power $[W] ; \eta=$ propeller efficiency, dimensionless.

The aircraft's range is given by:

$$
R=\frac{\eta}{c}\left(\frac{c_{L}}{c_{D}}\right) \ln \left(\frac{w_{0}}{w_{1}}\right)
$$

In which: $\mathrm{R}=$ aircraft range $[\mathrm{m}] ; \mathrm{c}=$ specific fuel consumption $\left[\mathrm{m}^{-1}\right] ; \mathrm{W}_{0}=$ gross weight of the aircraft (at the beginning of the mission) $[\mathrm{N}] ; \mathrm{W}_{\mathrm{i}}=$ weight of the aircraft at a given point in the mission $[\mathrm{N}]$;

$\frac{w_{i}}{w_{i+1}}=$ weight fraction of the segment of the mission, dimensionless.

The aircraft's autonomy (endurance) is given by:

$$
E=\frac{\eta}{C}\left(\frac{C_{L^{2}}}{C_{D}}\right)\left(2 \rho_{\infty} S\right)^{\frac{1}{2}}\left(W_{1}^{\frac{-1}{2}}-W_{0}^{\frac{-1}{2}}\right)
$$

In which: $\mathrm{E}=$ aircraft endurance $[\mathrm{s}] ; \rho_{\infty}=$ specific air mass $\left[\mathrm{kg} \mathrm{m}^{-3}\right]$.

The gross weight of an unmanned aircraft is given by:

$$
W_{0}=\frac{W_{\text {payload }}}{1-\left(w_{f} / w_{0}\right)-\left(w_{e} / w_{0}\right)}
$$

In which: $\mathrm{W}_{0}=$ aircraft gross weight $[\mathrm{N}] ; \mathrm{W}_{\text {payload }}=$ aircraft payload $[\mathrm{N}] ; \mathrm{W}_{\mathrm{f}}=$ aircraft fuel weight $[\mathrm{N}]$; $\mathrm{W}_{\mathrm{e}}=$ aircraft empty weight $[\mathrm{N}]$. 
The weight of the fuel by the gross weight ratio, considering a reserve of $6 \%$ in the fuel tank, is given by:

$$
\frac{w_{f}}{w_{0}}=1.06\left[1-\Pi_{i}\left(\frac{w_{i}}{w_{i-1}}\right)\right]
$$

Finally, the values assumed for the application of a pesticide for aerial spraying are presented in Table 1.

Table 1 - Initial Spraying Parameters.

\begin{tabular}{lcll}
\hline Spray volume applied per hectare ${ }^{(1)}$ & 20.0 & Dosage of the phytosanitary product ${ }^{(1)}$ & 2.0 \\
Band treated by nozzle (2) & 2.5 & Total spraying width $^{(2)}$ & 5.0 \\
\hline
\end{tabular}

(1) $\left[\mathrm{L} \mathrm{ha}^{-1}\right]^{\left({ }^{(2)}\right.}[\mathrm{m}]$.

Source: Elaborated by the authors (2020).

\section{Results and discussion}

With the values in Table 1, the flow rates to be used and the capacity of the spray tank are determined (TABLE 2). The aircraft has only two spray nozzles whose specifications are presented in Table 3.

Table 2 - Flow rate and volume of the spray tank.

\begin{tabular}{cccc}
\hline Flow by nozzle $^{(1)}$ & 8.82 & Total spraying flow ${ }^{(1)}$ & 17.64 \\
Amount of phytosanitary product ${ }^{(2)}$ & 2.00 & Tank Capacity ${ }^{(2)}$ & 20.00 \\
\hline
\end{tabular}

${ }^{(1)}\left[\mathrm{L} \mathrm{min}^{-1}\right]$ (International System). ${ }^{(2)}[\mathrm{L}]$.

Source: Elaborated by the authors (2020).

The spray nozzle is formed by the cover, tip, filter and body and the characteristics of the tips selected for the proposed AVANT are listed in Table 3.

Table 3 - Spray nozzle specifications.

\begin{tabular}{lclc}
\hline Nomenclature & 3023 & Manufacturing Material & Polyethylene \\
Minimum flow per nozzle ${ }^{(1)}$ & 1.6 & Maximum flow per nozzle ${ }^{(1)}$ & 3.0 \\
Spray angle & $30^{\circ}$ & Suitable filter Mesh & 35 \\
Work pressure $^{(2)}$ & 39.23 & Jet Shape & Rotary Conical \\
\hline
\end{tabular}

(1) $\left[\right.$ gal $\mathrm{min}^{-1}$ ] (American system, where 1.0 gal $_{\text {USA }}=3.785 \mathrm{~L}$ ). ${ }^{\text {(2) }}[\mathrm{kPa}]$.

Source: Elaborated by the authors (2020).

According to the computational simulation, in the first spray shot (first pass), the aircraft is operated at an angle of attack of $3^{\circ}$ and velocity of $37.4 \mathrm{~m} \mathrm{~s}^{-1}$, the speed decreases with each spray shot until the aircraft reaches the value of $21.4 \mathrm{~m} \mathrm{~s}^{-1}$ at an attack angle of $5^{\circ}$. Thus, in the first sprays, the flow per nozzle is $3.0 \mathrm{gal} \mathrm{min}^{-1}$ (approximately $11.3 \mathrm{~L} \mathrm{~min}^{-1}$ ), and decreases linearly, track by track, down to $1.7 \mathrm{gal} \mathrm{min}^{-1}$ (approximately $6.5 \mathrm{~L} \mathrm{~min}^{-1}$ ) in the $20^{\text {th }}$ spray shot (last pass). The average flow 
per nozzle is 2.3 gal $\mathrm{min}^{-1}$ (approximately $8.8 \mathrm{~L} \mathrm{~min}^{-1}$ ) at an average velocity of $29.4 \mathrm{~m} \mathrm{~s}^{-1}$. The aircraft weight varied from $143.8 \mathrm{~kg}$ in the first spray shot to $112.2 \mathrm{~kg}$ in the $20^{\text {th }}$ spray shot.

Table 4 - Flight and operation conditions.

\begin{tabular}{lcc}
\hline & Value & Unit \\
\hline Local altitude & 1100 & $\mathrm{~m}$ \\
Specific air mass & 1.1008 & $\mathrm{~kg} \mathrm{~m}^{-3}$ \\
Kinematic air viscosity & $1.5111 \times 10^{-5}$ & $\mathrm{~m} \mathrm{~s} \mathrm{~s}^{-1}$ \\
Operating velocity & 37.4 to 21.4 & $\mathrm{~m} \mathrm{~s}^{-1}$ \\
Operational capacity & 17 & $\mathrm{ha} \mathrm{h}^{-1}$ \\
Number of passes & 20 & {$[-]$} \\
Time for each pass & 3.4 & $\mathrm{~s}$ \\
Number of maneuvers & 19 & {$[-]$} \\
Average maneuver time & 6.0 & $\mathrm{~s}$ \\
Time to spray one hectare & 3.5 & $\mathrm{~min}$ \\
\hline
\end{tabular}

Source: Elaborated by the authors (2020).

Moreover, in the computational routines, the aircraft operates close to the ground and its operating altitude is very close to the local altitude. The particular flight conditions were presented in Table 4 and they are subsequently used.

As a result, with the parameters established for the spraying and the flight altitude defined, it is possible to determine that the operating speed should be around one hundred and thirty kilometers per hour. With this value of operational velocity, the aircraft is set to spray one hectare per mission.

The layout of the mission is presented in Figure 1a. This representation is scaled and the performance data of the AVANT in the spray shots and in the maneuvers are used. Figure $1 \mathrm{~b}$ shows the spraying area where the spray nozzles are schematized by "B1" and "B2". Figure 2 shows a side view of the application.

As for the overlap, Figure $1 \mathrm{~b}$ demonstrates a simulated case for a simple overlapping, with the AVANT at a height of $3 \mathrm{~m}$ from the target. To ensure the transverse uniformity of liquid distribution, the AVANT must be operated at a height of $6 \mathrm{~m}$ from the target for a double overlapping, or at a height of $9 \mathrm{~m}$ from the target for a triple overlapping.

In the present case, it is recommended to use double overlapping with the aircraft at a flight height of $6 \mathrm{~m}$, to ensure uniform distribution of the product. At this height of the flight, there might be a risk of recirculation. 
Figure 1 - (a) Flight plane, in which the solid line represents the Spray Shot, the dashed line the maneuver, and the quadratic area is one hectare, (b) Application top view.

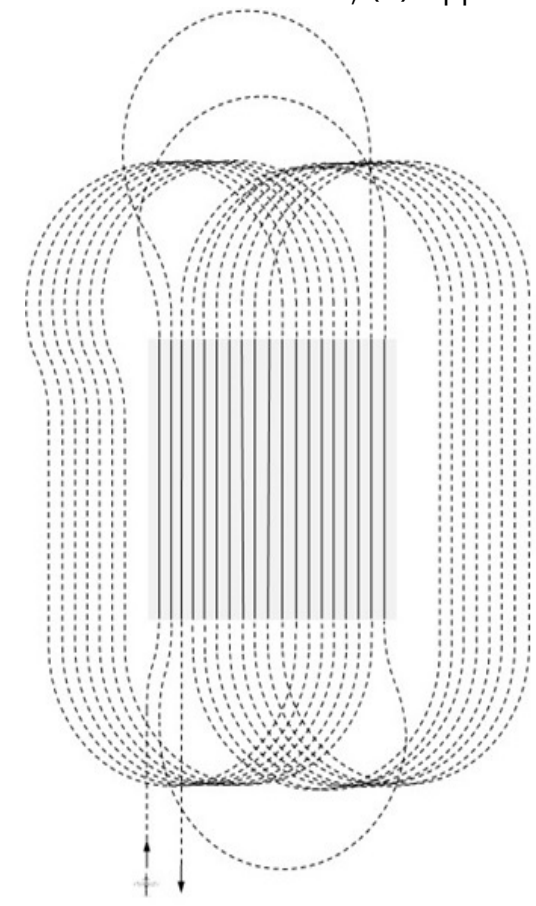

(a)

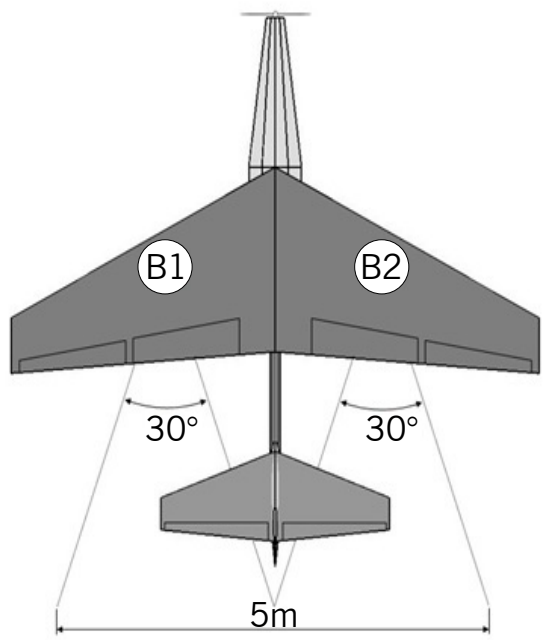

(b)

Source: Elaborated by the authors (2020).

Figure 2 - Side view of the application.

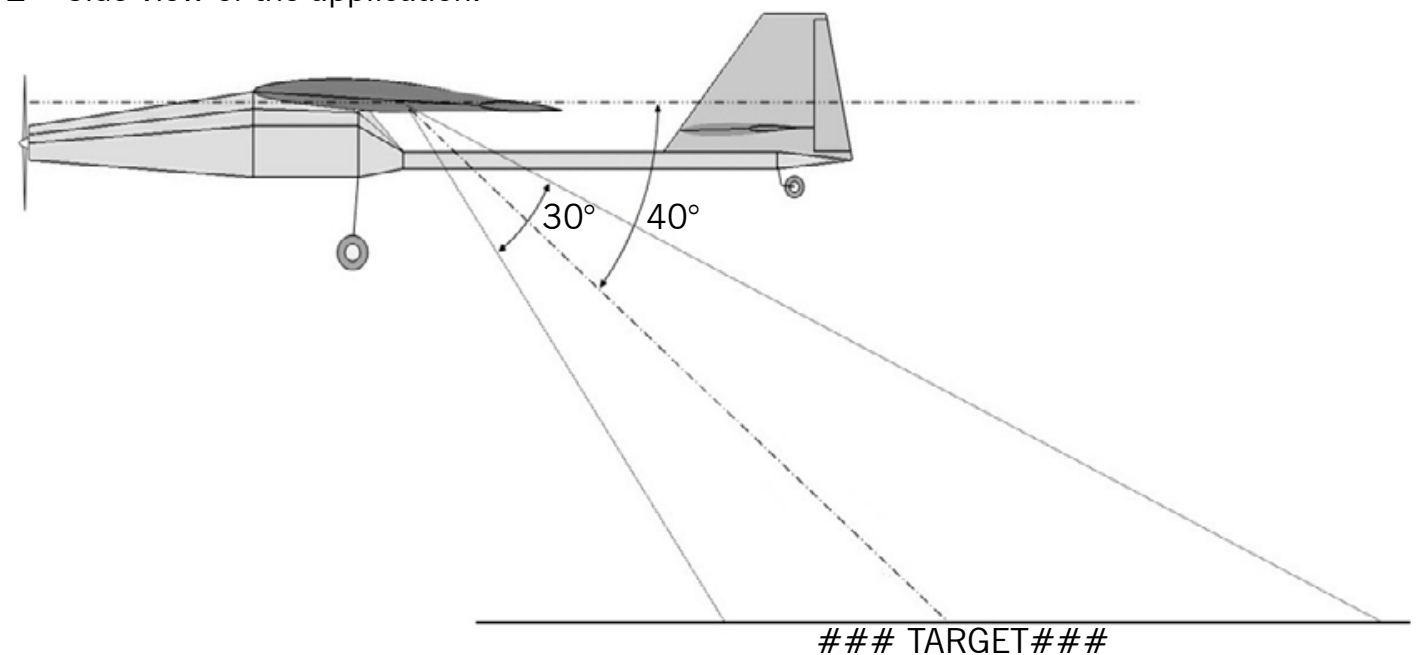

Source: Elaborated by the authors (2020).

The wing has the following characteristics: wingspan of $6 \mathrm{~m}$, root chord of $1.850 \mathrm{~m}$, tip chord of $0.555 \mathrm{~m}$, wing load of $204 \mathrm{~N} \mathrm{~m}^{-2}$, a taper ratio of 0.3 , aspect ratio of 5 , and NACA 65-210 aerodynamic profile. The geometry characteristics of the horizontal tail are: wingspan of $2.6 \mathrm{~m}$, root chord of $0.90 \mathrm{~m}$, tip chord of $0.32 \mathrm{~m}$, an aspect ratio of 4.26 , a taper ratio of 0.36 , and NACA 0009 profile. The characteristics of the vertical tail are: wingspan of $0.8595 \mathrm{~m}$, root chord of $1.300 \mathrm{~m}$, tip chord of $0.419 \mathrm{~m}$, an aspect ratio of 2, a taper ratio of 0.32 , and NACA 0009 profile. Additional details are shown in Table 5. 
Table 5 - Aircraft loading.

\begin{tabular}{lcr}
\hline & Symbology & Value Unit \\
\hline Gross weight & $W_{0}$ & $150 \mathrm{~kg}$ \\
Payload & $W_{\text {payload }}$ & $20 \mathrm{~kg}$ \\
Empty weight & $W_{e}$ & $108.585 \mathrm{~kg}$ \\
Fuel weight & $W_{f}$ & $21.415 \mathrm{~kg}$ \\
Empty weight by gross weight ratio & $W_{e} / W_{0}$ & $0.72[-]$ \\
Fuel weight by gross weight ratio & $W_{f} / W_{0}$ & $0.14[-]$ \\
\hline
\end{tabular}

Source: Elaborated by the authors (2020).

The selected fuel is gasoline and, because of its density, it resulted in a tank with 28 liters to complete the entire mission. Table 6 presents the project parameters of the spraying UAV. Therefore, by selecting the aircraft conventional/propeller engine set, it was possible to draw the power curves against the velocity as shown in Figure 3. With the aerodynamic parameters defined, the agricultural UAV is shown in Figure 4 and the general characteristics are presented in Table 7.

Table 6 - Aircraft project parameters.

\begin{tabular}{|c|c|c|c|}
\hline Zero lift drag coefficient $\left(C_{D 0}\right)$ & 0.0266 & Oswald Factor (e) & 0.94 \\
\hline $\begin{array}{l}\text { Maximum aerodynamic efficiency } \\
\left(\frac{C_{L}}{c_{D}}\right)_{\max }\end{array}$ & 12.2 & $\left(\frac{C_{L}^{\frac{3}{2}}}{C_{D}}\right)_{\max }$ & 10.6 \\
\hline
\end{tabular}

Source: Elaborated by the authors (2020).

Figure 3 - Power vs. velocity Curves.

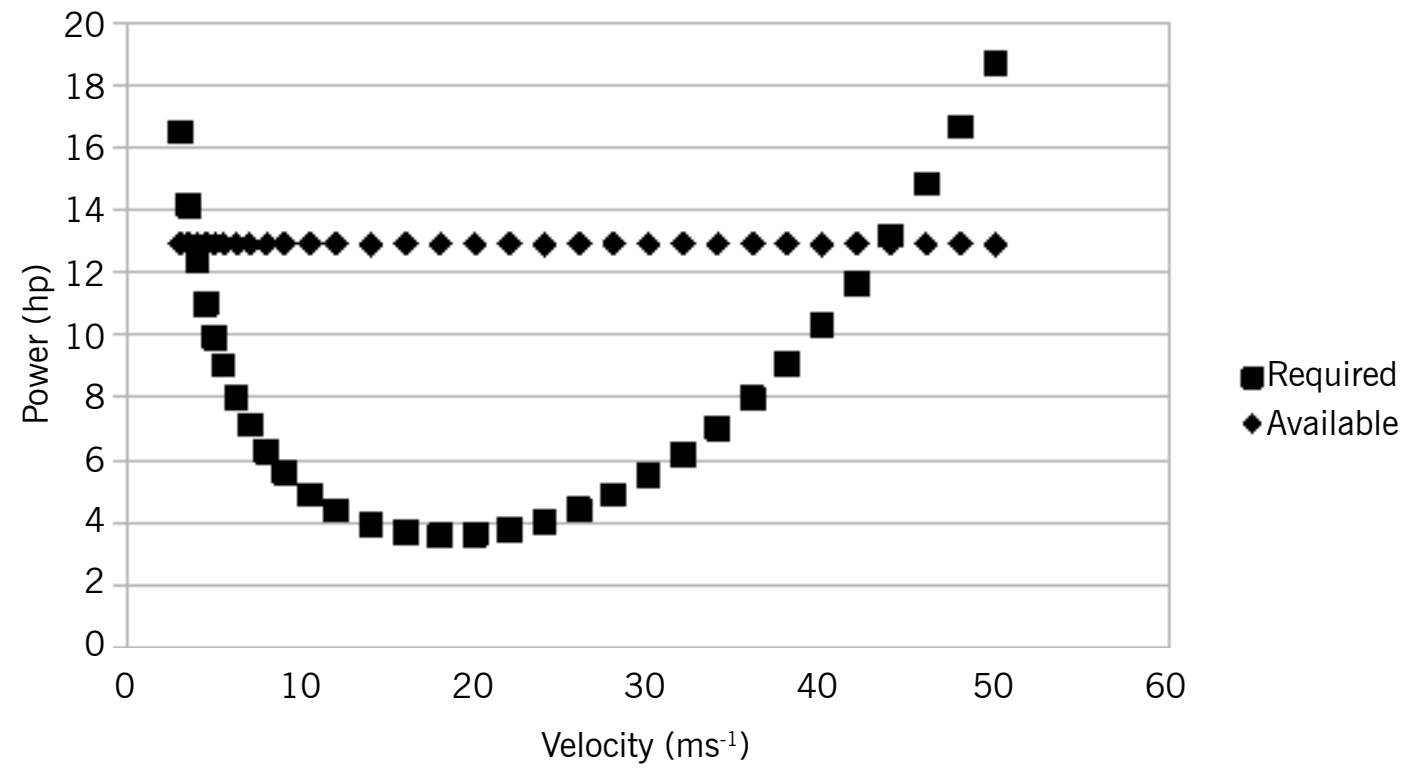

Source: Elaborated by the authors (2020). 
Figure 4 - Diagram of three views of the AVANT.
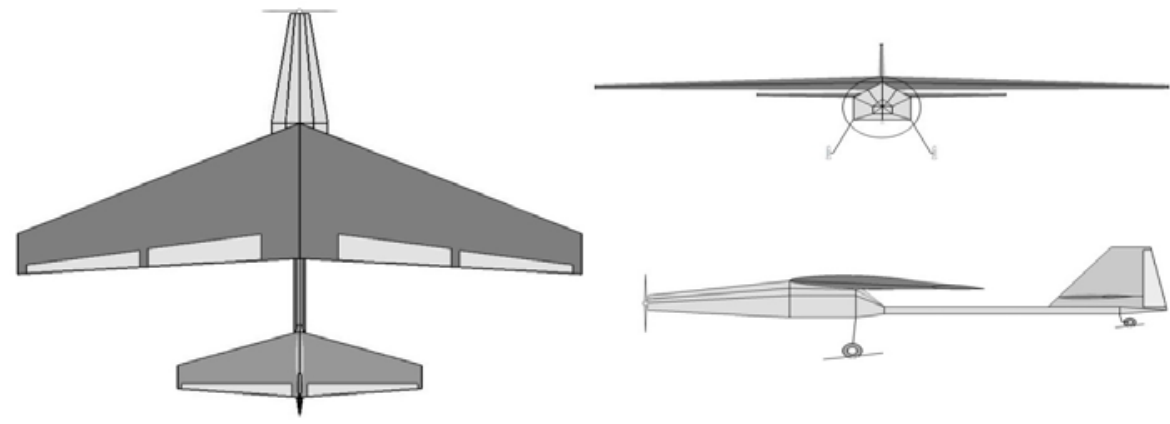

Source: Elaborated by the authors (2020).

Table 7 - Final characteristics of the AVANT.

\begin{tabular}{|c|c|c|c|}
\hline Wingspan $^{(1)}$ & 6.0 & Length $^{(1)}$ & 5.5 \\
\hline Height $^{(1)}$ & 1.477 & Wheel base ${ }^{(1)}$ & 2.955 \\
\hline Gear tread ${ }^{(1)}$ & 1.108 & Wing configuration & High wing \\
\hline Engine (2) & Single-engine propeller /ICE & Installed power ${ }^{(4)}$ & 18.0 \\
\hline Type of landing gear & Taildragger & Maximum endurance ${ }^{(5)}$ & 9.0 \\
\hline Maximum range ${ }^{(3)}$ & 690 & Runway length (6) & 150 \\
\hline
\end{tabular}

(1) [m]. (2) ICE: internal combustion engine (Conventional radial engine). (3) [km], Typical configuration of simple cruise (approximately). ${ }^{(4)}$ [hp]. ${ }^{(5)}$ [h], Typical configuration of simple cruise (approximately) ${ }^{(6)}$ [m], it is the amount required with maximum weight for takeoff at an altitude of $1100 \mathrm{~m}$ at a temperature of $15^{\circ} \mathrm{C}$ (approximately).

Source: Elaborated by the authors (2020).

The aerodynamic project resulted in an aircraft with adequate aerodynamic efficiency, stability, and controllability, being an agricultural machine that needs a low installed power, which provides low fuel consumption when related to its load capacity and operational field.

Figure 5 - Center of Gravity Tour in the longitudinal axis of the aircraft.

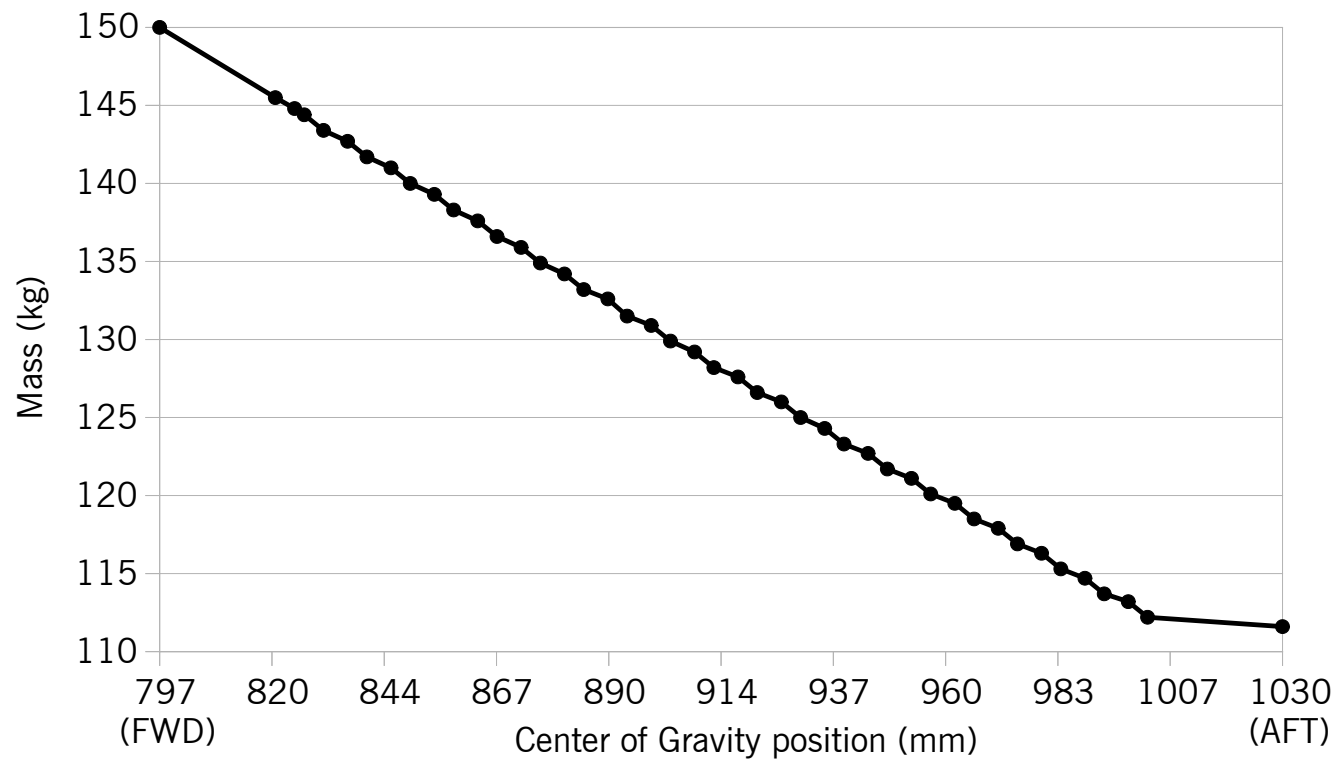

Source: Elaborated by the authors (2020). 
Figure 5 shows the forward position of the center of gravity (CG) at the beginning of the mission, called FWD (forward) and the reverse position of the center of gravity at the end of the mission, called AFT (afterward). Finally, the tour of the center of gravity of the Agricultural UAV is presented. The position of the center of gravity started at $13.4 \%$ of Mean Aerodynamic Chord (MAC), FWD, and ended at $31.5 \%$ MAC (AFT), having the mean value of $22.5 \%$ of MAC, a value very close to the value of $24 \%$ of MAC found by Liu et al. (2018) for the Boeing B737-800. The neutral point was $36.4 \%$ of MAC (FIGURE 6). Due to the variation in the position of the center of gravity, there is variation in the operation velocity, resulting in variation of the total flow of the two nozzles to maintain a constant and invariable value of the application rate. Accordingly, the aircraft angle of attack is $0.3^{\circ}$ in the first simulated pass and $4.8^{\circ}$ for the last pass linear with the spray shot (TABLE 8 ).

Table 8 - Total spray flow variation for each spray shot.

\begin{tabular}{|c|c|c|c|c|c|}
\hline & Velocity ${ }^{(1)}$ & Total Flow (2) & & Velocity ${ }^{(1)}$ & Total Flow ${ }^{(2)}$ \\
\hline $1^{\text {st }}$ Shot & 37.4 & 3.0 & $11^{\text {th }}$ Shot & 29.0 & 2.3 \\
\hline $2^{\text {nd }}$ Shot & 36.6 & 2.9 & $12^{\text {th }}$ Shot & 28.1 & 2.2 \\
\hline $3^{\text {rd }}$ Shot & 35.7 & 2.9 & $13^{\text {th }}$ Shot & 27.3 & 2.2 \\
\hline $4^{\text {th }}$ Shot & 34.9 & 2.8 & $14^{\text {th }}$ Shot & 26.5 & 2.1 \\
\hline $5^{\text {th }}$ Shot & 34.0 & 2.7 & $15^{\text {th }}$ Shot & 25.6 & 2.0 \\
\hline $6^{\text {th }}$ Shot & 33.2 & 2.7 & $16^{\text {th }}$ Shot & 24.8 & 2.0 \\
\hline $7^{\text {th }}$ Shot & 32.3 & 2.6 & $17^{\text {th }}$ Shot & 23.9 & 1.9 \\
\hline $8^{\text {th }}$ Shot & 31.5 & 2.5 & $18^{\text {th }}$ Shot & 23.1 & 1.8 \\
\hline $9^{\text {th }}$ Shot & 30.7 & 2.5 & $19^{\text {th }}$ Shot & 22.2 & 1.8 \\
\hline $10^{\text {th }}$ Shot & 29.8 & 2.4 & $20^{\text {th }}$ Shot & 21.4 & 1.7 \\
\hline
\end{tabular}

(1) $\left[\mathrm{m} \mathrm{s}^{-1}\right.$. (2) [gal $\mathrm{min}^{-1}$ ], considering the two nozzles (1 gal $=3.785 \mathrm{~L}$ ).

Source: Elaborated by the authors (2020).

In the case of a Tail dragger, the agricultural UAV due to its project, at the beginning of the takeoff and with all the wheels of the main and auxiliary landing gear in contact with the runway, the aircraft attack angle was $8^{\circ}$. After the takeoff, the aircraft starts the mission with an operational speed of $40.2 \mathrm{~m} \mathrm{~s}^{-1}$.

It should be emphasized that Ribeiro et al. (2017) presented the results of a modeling study of a civil aircraft to increase its aerodynamic efficiency and reached numerical results similar to the results achieved by the present Agricultural UAV (AVANT), having an aerodynamic efficiency of 12 and a drag coefficient of 0.3 .

The comparison of the proposed UAV with a commercial manned agricultural airplane shows a lower fuel consumption ( $5 \mathrm{~L} \mathrm{~h}^{-1}$ against $65 \mathrm{~L} \mathrm{~h}^{-1}$ ), a shorter take-off distance (132 m against $564 \mathrm{~m}$ ), a lower cost for farmers (due to the initial investment around one-tenth of the current airplane) and the humanization of agricultural spray operation. Due to its relatively small dimensions, approximately five aircraft of the proposed design are required to perform the same task as the commercial manned aircraft.

\section{Conclusion}

The results of computational simulations show that the proposed aircraft (a monoplane, called AVANT by the authors) is adequate for the proposed application and performance. Simulations 
were realized to verify the performance of the airplane during the operational shots and maneuvers. Operational fuel costs and other operational parameters were compared and evaluated, resulting in an aircraft adequate for the conditions of spraying.

With the computer simulation, AVANT's wing aerodynamic profile and its agricultural spraying operation were selected, to enable the AVANT wing, fuselage, landing gear and tail to be designed to suit the speed, altitude and loading required. Still in the simulation, the behavior and stability of the aircraft were evaluated shot by shot throughout the spraying operation.

AVANT has fuel consumption approximately $20 \%$ lower compared to currently available agricultural monoplanes. AVANT also has an adequate aerodynamic efficiency of 12 . However, the most important feature of the AVANT is aiming at the humanization of agricultural operations.

After all, the geometry and aerodynamic performance of the proposed AVANT resulted in a low-cost aircraft with low-fuel consumption, because of its fuselage geometry and installed power, respectively. There was no product built, the final product of this work is the numerical results of the computer simulations.

\section{Acknowledgments}

The authors wish to thank the National Council for Scientific and Technological Development CNPq for the PQ Research Grant 304372/2016-1. In the same way, the authors wish to thank the UNICAMP and IFSULDEMINAS.

\section{Conceito e simulação de uma aeronave de pulverização agrícola não tripulada}

\section{Resumo}

Nos últimos anos, a produção agrícola brasileira cresceu 900 \% em relação a 1990, enquanto as áreas cultivadas aumentaram a uma taxa de $2 \%$ ao ano. Devido a essa expansão, a pulverização passou de manual para mecânica utilizando equipamentos de solo e aeronaves. Como resultado dessas novas tendências, estatísticas recentes mostram que há impactos negativos na saúde dos pilotos e operadores de máquinas terrestres e no meio ambiente. 0 presente estudo avalia o conceito de veículo aéreo não tripulado (VANT) para pulverização de produtos defensivos, aqui denominado AVANT. Neste estudo, novos aerofólios são avaliados, a teoria da linha de sustentação, o método da malha de vórtices e o método dos painéis são usados para definir a geometria da asa, fuselagem e elementos da cauda. Simulações foram realizadas para verificar o desempenho do AVANT durante as linhas de pulverização e manobras operacionais. Os parâmetros básicos do AVANT propostos são: Envergadura: 6 m; Monoplano; Asa alta; Motor de pistão (gasolina); Hélice; Tipo Tractor; Potência instalada: $18 \mathrm{cv}$; Comprimento: 5,5 m; Altura: 1,477 m; Tipo Taildragger; Largura da cauda: 2,6 m; Peso vazio: 108,585 kg; Peso bruto: 150 kg; Autonomia máxima: 9 h; Capacidade do tanque de combustível: 28 L; Capacidade do tanque de agroquímicos: 20 L. Os resultados mostram que o AVANT é adequado para a aplicação proposta.

Palavras-chave: Aerodinâmica. Agricultura. Pesticidas. UAV. 


\section{References}

ABUBAKAR, M.; MALA, M.; MUMIN, A.; ZAINAB, T.; FATIMA, A. Perceptions of environmental effects of pesticides use in vegetable production by farmers along River Ngadda of Maiduguri, Nigeria. J Agric Environ Sci [Internet], v. 4, n. 1, p. 212-5, 2015. https://dx.doi.org/10.15640/jaes.v4n1a26.

BURALLI, R.J.; RIBEIRO, H.; MAUAD, T.; AMATO-LOURENÇO, L.F.; SALGE, J.M.; DIAZ-QUIJANO, F.A.; LEÃO, R.S.; MARQUES, R.C.; SILVA, D.S.; GUIMARÃES, J.R.D. Respiratory condition of family farmers exposed to pesticides in the state of Rio de Janeiro, Brazil. International journal of environmental research and public health, v. 15, n. 6, p. 1203, 2018. https://doi.org/10.3390/ijerph15061203.

CHAIM, A. Eficiência de aplicação. Embrapa de Informação Tecnológica.(2019) Available at: http://www. agencia.cnptia.embrapa.br/gestor/agricultura_e_meio_ambiente/arvore/CONTAG01_44_210200792814. html/. Accessed on: 12 dec. 2019.

FAIÇAL, B. S.; COSTA, F. G.; PESSIN, G.; UEYAMA, J.; FREITAS, H.; COLOMBO, A.; FINI, P. H.; VILLAS, L.; OSÓRIO, F. S.; VARGAS, P. A.; BRAUN, T. The use of unmanned aerial vehicles and wireless sensor networks for spraying pesticides. Journal of Systems Architecture, v. 60, n. 4, p. 393-404, 2014.

FAIÇAL, B. S.; FREITAS, H.; GOMES, P. H.; MANO, L. Y.; PESSIN, G.; DE CARVALHO, A. C.; KRISHNA MACHARI, B.; UEYAMA, J. An adaptive approach for UAV-based pesticide spraying in dynamic environments. Computers and Electronics in Agriculture, v. 138, p. 210-223, 2017.

GABOR, O. Ş.; KOREANSCHI, A.; BOTEZ, R. M. A new non-linear vortex lattice method: Applications to wing aerodynamic optimizations. Chinese Journal of Aeronautics, v. 29, n. 5, p. 1178-1195, 2016. https://doi.org/10.1016/j.cja.2016.08.001.

HUANG, Y.; HOFFMANN, W. C.; LAN, Y.; WU, W.; FRITZ, B. K. Development of a spray system for an unmanned aerial vehicle platform. Applied Engineering in Agriculture, v. 25, n. 6, p. 803-809, 2009.https://doi.org/10.13031/2013.29229.

JAFARIMOGHADDAM, A.; ABEROUMAND, S. Introducing an optimized airfoil shape using panel method, a short report. Eur. J. Adv. Eng. Technol,v. 3, n. 7, p. 47-52, 2016.http://www.ejaet.com/ PDF/3-7/EJAET-3-7-47-52.pdf/.

JUNQUEIRA, L. E. A. R.; CONTRERA, L. Occupational Exposure to Agrochemicals: A Literature Review. In: Congress of the International Ergonomics Association. Springer, Cham, 2018. p. 31-34. https://doi.org/10.1007/978-3-319-96098-2_5.

KELLY, M. R.; COHEN, R. A. The Effects of an Herbicide and Antibiotic Mixture on Aquatic Primary Producers and Grazers. Bulletin of environmental contamination and toxicology, v. 101, n. 5, p. 556-561, 2018.

LING, W.; DU, C.; ZE, Y.; SHUMAO, W. Research on the prediction model and its influencing factors of droplet deposition area in the wind tunnel environment based on UAV spraying. IFAC-PapersOnLine, v. 51, n. 17 , p. $274-279,2018$. 
LIU, Y.; YANG, Z.; DENG, J.; ZHU, J. Investigation of fuel savings for an aircraft due to optimization of the center of gravity. In: International Symposium on Application of Materials Science and Energy Materials (SAMSE). Shanghai, 2018.

MARCELINO, A. F.; WACHTEL, C. C.; GHISI, N. C. Are Our Farm Workers in Danger? Genetic Damage in Farmers Exposed to Pesticides. International journal of environmental research and public health, v. 16, n. 3, p. 358, 2019.

MATSUO, C. A. S.; ISMAIL, K. A. R. Otimização do aerofólio NACA para um veículo aéreo não tripulado com aplicação agrícola. Mecánica Computional,v. 29, n. 1, p. 3657-69, 2010. https://dx.doi.org/10.13140/2.1.3845.4562.

MEIVEL, S. M. E.; MAGUTEESWARAN, R.; GANDHIRAJ, N. B. E.; SRINIVASAN, G. Quadcopter UAV based fertilizer and pesticide spraying system. Journal Engeenering Science,v. 1, n. 1, p. 8-12, 2016.

MOGILI, U. R.; DEEPAK, B. B. V. L. Review on application of drone systems in precision agriculture. Procedia Computer Science, v. 133, p. 502-509, 2018.https://doi.org/10.1016/j.procs.2018.07.063.

OJO, J. Pesticides use and health in Nigeria. Ife J of Sci, v. 18, n. 4, p. 981-991, 2016.

PALLADINI, L. A. Aplicação de Agrotóxicos, Riscos, Legislação de Aplicação de Agrotóxicos. 2019. Available at: https://www.portalsaofrancisco.com.br/biologia/aplicacao-de-agrotoxicos/. Accessed on: 23 Apr. 2019.

RAMOS - GARCÍA, N.; SØRENSEN, J. N.; SHEN, W. Z. Three-dimensional viscous-inviscid coupling method for wind turbine computations. Wind Energy, v. 19, n. 1, p. 67-93, 2016. https://doi.org/ 10.1002/we.1821.

REEVES, W. R.; MCGUIRE, M. K.; STOKES, M.; VICINI, J. L. Assessing the Safety of Pesticides in Food: How Current Regulations Protect Human Health. Advances in Nutrition, v. 10, n. 1, p. 80-88, 2019.https://doi.org/10.1093/advances/nmy061.

RIBEIRO, F. C.; PAULA, A. A.; SCHOLZ, D.; SILVA, R. G. A. Wing geometric parameter studies of a box wing aircraft configuration for subsonic flight. In: 7thEuropean Conference for Aeronautics and Space Sciences (EUCASS 2017), Milan.

SENA, T. R. R.; DOURADO, S. S. F.; LIMA, L. V.; ANTONIOLLI, Â. R. The hearing of rural workers exposed to noise and pesticides. Noise \& health, v. 20, n. 92, p. 23, 2018.

SCHMIDT, F.; ZANELLA, S. J. Avaliações qualitativas de pulverizadores agrícolas em propriedades rurais na região de Erechim-RS. Revista em Agronegócio e Meio Ambiente, v. 10, n. 3, p. 633-652, 2017.http://dx.doi.org/10.17765/2176-9168.2017v10n3p633-652.

SILVA, S. A.; ALVARENGA, C. B.; LIMA, J. S. S.; SILVA, M. A. Spatial quality assessment of pesticide applications using a cannon sprayer. Engenharia na Agricultura. v. 23, n. 5, p. 418-427, 2015. https://doi.org/10.13083/reveng.v23i5.527. 
WACHTEL, C. C.; OLIVEIRA, E. C.; MANIGLIA, T. C.; SMITH-JOHANNSEN, A.; ROQUE, A. A., GHISI, N. C. Waterborn Genotoxicity in Southern Brazil Using Astyanax bifasciatus (Pisces: Teleostei). Bulletin of environmental contamination and toxicology, v. 102, n. 1, p. 59-65, 2019.

WANG, G.; LAN, Y.; QI, H.; CHEN, P.; HEWITT, A.; HAN, Y. Field evaluation of an unmanned aerial vehicle (UAV) sprayer: effect of spray volume on deposition and the control of pests and disease in wheat. Pest management science, v. 75, n. 6, p. 1546-1555, 2019. https://doi.org/10.1002/ps.5321.

WANG, X.; HE, X.; WANG, C.; WANG, Z.; LI, L.; WANG, S.; WANG, Z. Spray drift characteristics of fuel powered single-rotor UAV for plant protection. Transactions of the Chinese Society of Agricultural Engineering, v. 33, n. 1, p. 117-123, 2017.

WEN, S.; ZHANG, Q.; YIN, X.; LAN, Y.; ZHANG, J.; GE, Y. Design of Plant Protection UAV Variable Spray System Based on Neural Networks. Sensors, v. 19, n. 5, p. 1112, 2019. https://doi.org/10.3390/ s19051112.

XUE, X.; LAN, Y.; SUN, Z.; CHANG, C.; HOFFMANN, W.C. Develop an unmanned aerial vehicle based automatic aerial spraying system. Computers and electronics in agriculture, v. 128, p. 58-66, 2016. https://doi.org/10.1016/j.compag.2016.07.022.

YANAGIHARA, D.; BRAGAGNOLO, C. Cost-benefit of the reverse logistics of empty packaging of agrochemicals in Brazil. Revista iPecege, v. 4, n. 2, p. 16-24, 2018. http://dx.doi.org/10.22167/ r.ipecege.2018.2.16.

YONGJUN, Z.; SHENGHUI, Y.; CHUNJIANG, Z.; LIPING, C.; LAN, Y.; YU, T. Modelling operation parameters of UAV on spray effects at different growth stages of corns. International Journal of Agricultural and Biological Engineering, v. 10, n. 3, p. 57-66, 2017.

YU, Y.; GUAN, Z. Learning from bat: aerodynamics of actively morphing wing. Theoretical and Applied Mechanics Letters, v. 5, n. 1, p. 13-15, 2015.

ZHANG, Y.; LI, Y.; HE, Y.; LIU, F.; CEN, H.; FANG, H. Near ground platform development to simulate UAV aerial spraying and its spraying test under different conditions. Computers and electronics in agriculture, v. 148, p. 8-18, 2018.

ZHU, H.; LAN, Y.; WU, W.; HOFFMANN, W. C.; HUANG, Y.; XUE, X.; LIANG, J.; FRITZ, B. Development of a PWM precision spraying controller for unmanned aerial vehicles. Journal of Bionic Engineering, v. 7, n. 3, p. 276-283, 2010.

Received: December 13, 2019

Accepted: June 8, 2020. 